which is thus added to the few mammalian genera that have come down to us unmodified from older Cainozoic times.

A wide interest is attached to the investigation of the "Paleocene Deposits of the San Juan Basin, New Mexico," by W. J. Sinclair and W. Granger (Bull. Amer. Mus. Nat. Hist., vol. xxiii., 1914, p. 297), since these beds contain the oldest known Cainozoic mammals. The famous Puerco clays rest unconformably on a conglomerate with silicified tree-stems, below which are shales containing deinosaurs. No deinosaurs have been found in the Puerco Beds, and the faunal change is even here remarkably abrupt. Fossil plants, of no stratigraphical import, have been found for the first time (p. 306) in the Puerco Beds.

Among faunistic papers, we may note that the indefatigable C. D. Walcott reviews, with a bibliography, the "Cambrian Faunas of Eastern Asia" (Smithson. Miscell. Coll., vol. 1xiv., xoI4, p. I).

$$
\text { G. A. J. C. }
$$

\section{THE PLACE OF LAVOISIER IN THE HISTORY OF CHEMISTRY.}

A SOMEWHAT novel view of "The Place of Lavoisier in the History of Chemistry " is put forward in a paper contributed by A. Mieli to the April number of Scientia. This question has formed the subject of prolonged controversy, and has called forth the most diverse and contrary opinions. Some, with Wurtz, have boldly acclaimed the fact that "Chemistry is a French science. Its founder is Lavoisier, of immortal memory." Others have written him down as a mere plagiarist, who purloined from Priestley the discovery of oxygen, and from Cavendish the discovery of the composition of water, and thus built up a great reputation on the unacknowledged work of his English colleagues. The Italian writer asserts that these claims and counterclaims are based upon a misconception. Lavoisier's true place is not at the beginning of the period to which the atomic and molecular theories belong, but at the close of an earlier period in which the chief problems were the nature of combustion, and the composition of air and water. This period opens with Jean Rey and Boyle; John Mayow had practically reached a true solution of the main problems in 1674; but Becher and Stahl intervened, and it was only by the work of Black, Priestley, Cavendish, and Lavoisier that all difficulties and doubts were finally cleared away. Lavoisier's position in the historical sequence enabled him to use all the information and experience that had been gathered during the preceding ${ }_{1} \mathrm{O}$ years, and it was right that he should do so, though his acknowledgments to Priestley and to Cavendish might well have been more generous.

But whilst Lavoisier contributed a brilliant finale to the earlier period, his work cannot be regarded as forming in any sense an overture to the period which followed. The chief topics to be studied in the later period were those which were concerned with atoms, molecules, and equivalents. This period began with Dalton's atomic theory and the controversy between Proust and Berthollet on the subject of fixed or variable proportions ; Avogadro (like Mayow) almost solved the problem; but once again a long interval of doubt and confusion ensued, until at last the work of Dumas, Laurent, and Gerhardt, and, above all, St. Claire Deville's discovery of dissociation, enabled Cannizzaro to put forward the masterly exposition which finally dispelled the uncertainty and perplexity which had afflicted chemistry for nearly forty years.

Cannizzaro, like Lavoisier, owed much to others. His experimental wortz was on a much smaller scale than Lavoisier's ; but he is universally honoured as the man who cleared away the obstacles that had hindered the progress of knowledge during many weary years. Lavoisier's chief claim to immortality is of a similar character. It rests upon the fact that he was able to break through the entrenched lines of the "phlogiston" theory, and to make a broad gap through which others could enter the open plain beyond. His tragic death prevented him from reaping the full fruits of his victory over error, and it was left to others to undertake the conquest of the fertile country into which he had opened the way.

The periods suggested by the author are described in a paper communicated to the Italian Chemical Society (Rendiconti Soc. Chim. Ital., r9I4, vol. viii.) as follows :-

(I) The Philosophic Period, 600 to 300 B.C., including the writings of Empedocles, Aristotle, and others. (2) The Ancient Alchemistic Period, extending to about IOOO A.D., and dominated by the writings of Geber. (3) The Alchemistic Period of the Middle Ages, extending to about 1400 A.D., and including such names as Avicenna, Roger Bacon, Raymond Lully, Albertus Magnus, and the pseudo-Geber. (4) The Period of the Renaissance, including the work of Agricola (1494-1555), Bernard Palissy, and Paracelsus (I493-154I). (5) The Iatro-Chemical Period, originating with Paracelsus, and culminating in the work of van Helmont (1577-I644). (6) The Pneumatic Period, beginning with Boyle, including Stahl, Black, Cavendish. Priestley, and Scheele, and brought to its conclusion by Lavoisier. (7) The Period of the Modern Atomic Theory, beginning with Dalton, carried forward by Gay Lussac, Avogadro, Ampère, Davy, and Berzelius, and brought to completion bv the exposition of Cannizzaro. (8) The Period of Organic Chemistry and of the Periodic Law, including Liebig Wöhler, and Dumas, on the one side, Mendeléeff and Lothar Meyer on the other. (9) The Period of Physical Chemistry, originating with van't Hoff and Arrhenius. (ro) The period of Radio-activity.

T. M. L.

\section{FISHERY RESEARCH IN INDIA. ${ }^{1}$}

MR. SOUTHWELL deserves the thanks of those $\mathrm{N}$ interested in the better organisation of Imperial resources for summarising the history of fisheries research in India. That dates back only to 1906, for the work of Dr. Francis Day and Colonel Alcock was purely systematic. In 1906 economic research was initiated. Sir K. Gupta, then about to retire from the higher ranks of the Indian Civil Service, was ordered to inquire into the fisheries of Bengal. This officer tells us himself that he "knew nothing of fish," and that he "had not even done anything with the rod and line." Nevertheless, he made a lengthy tour in Europe and America to see those who did know, and on his return to India a Bengal Fisheries Department was established, with Mr. A. Ahmed as Commissioner.

The Department then obtained the services, for a year or so, of Dr. J. T. Jenkins, and an English steam trawler, the Golden Crown, was sent out to make a survey of the fishing grounds in the Bay of Bengal. While this was going on Mr. Ahmed established a Board which met five times, after which he "ceased to be Commissioner." The result of a very imperfect survey was the formation of a Fishery Department consisting of two directors of agriculture ("whose knowledge of the fisheries is necessarily of an entirely administrative nature"), of Mr. Southwell himself (a trained zoologist), as deputy-director, and

I Report on Fishery Investigations in Bengal, etc. with Recommendation for Future Work. By T. Southwell, Deputy Director of Fisheries for Bengal, etc. Bulletin No. 5. Department of Fi-heries, Bengal. (Calcutta: The Bengal Secretariat Book Depot, rgr5.) Price 6d.

No. 2378 , VOL. 95] 